\title{
Directors' Independence, Internal Audit Function, Ownership Concentration and Earnings Quality in Malaysia
}

\author{
Ahmed Hussein Al-Rassas ${ }^{1} \&$ Hasnah Kamardin ${ }^{1}$ \\ ${ }^{1}$ School of Accountancy, College of Business, Universiti Utara Malaysia, Kedah, Malaysia \\ Correspondence: Ahmed Hussein Al-Rassas, School of Accountancy, College of Business, Universiti Utara \\ Malaysia, Kedah, Malaysia. Tel: 60-17-508-5870. E-mail: aalrasas@gmail.com
}

Received: February 1, 2015 Accepted: February 23, 2015 Online Published: May 15, 2015

doi:10.5539/ass.v11n15p244 URL: http://dx.doi.org/10.5539/ass.v11n15p244

\begin{abstract}
Concentration of ownership in Malaysian public listed companies contributes to agency conflict between majority and minority shareholders. An effective monitoring mechanism is critical to mitigate this conflict. The study aims to examine the influence of board and audit committee independence, internal audit function and ownership concentration on earnings quality proxied by discretionary accruals. The sample of the study 508 companies listed on the Bursa Malaysia Main Market from 2009 to 2012. Two measures of discretionary accruals are used: Modified Jones model (Dechow et al., 1995); and extended Modified Jones Model (Yoon et al., 2006). Using OLS regression, results of the study suggest that audit committee independence and more investment in internal audit function are related to higher earnings quality. However, board of directors' independence and ownership concentration are associated with lower earnings quality. The finding indicates the importance of audit committee independence in producing quality financial reporting. Consistent findings are found for most variables in both models. The findings of the study have implication on the use of measurement of discretionary accruals in earnings quality studies and corporate governance practices in Malaysia.
\end{abstract}

Keywords: board independence, audit committee, internal audit function, ownership concentration, discretionary accruals, earnings quality, Malaysia

\section{Introduction}

The main objective of organizations is to ensure customers, investors, creditors, suppliers, regulators and the public at large that they are operating responsibly towards more accurate financial information (Abdullah, 1999). This can be achieved through gaining the confidence of all parties to invest in the businesses. Evidence from the financial crisis in 1997 has shown the effect of poor corporate governance and lack of transparency in financial reporting. Good corporate governance practices and transparency of financial reporting can enhance the investors' confidence (Hashim, 2007).

Concerns about the earnings management relationship with the recent high-profile scandals in accounting have caused the investing community to demand for higher earnings quality for the purpose of enhancing the financial statements quality (Bedard \& Johnstone, 2004). Discretionary accruals have received much attention among academics as well as investors as an important indicator of earnings quality.

The agency theory and resource dependence theory draw attention to the importance of directors' independence in monitoring the management's activities (Fama \& Jensen, 1983; Pfeffer \& Salancik, 2007). The independence of the board of directors and audit committee from the management can reduce uncertainty about the quality of financial reporting as a result of improved flow of information between the firms and stakeholders. Also, more investment in internal audit function increase the internal control of reported earnings process and increase the integrity of financial reporting quality (Al-Shetwi, Ramadili, Chowdury, \& Sori, 2011; Prawitt, Smith, \& Wood).

From the agency theory perspective, ownership concentration might lead to conflict of interests between the majority and minority shareholders, whereby the majority shareholders tend to expropriate the firm's resources (Porta, Lopez-De-Silanes, \& Shleifer, 1999; Shleifer \& Vishny, 1986).

Based on the above discussion, we examine the association between the independence of board of directors and audit committee, internal audit function and ownership concentration and earnings quality. This study extends the prior literature in several ways. First, this study is the first study to apply the extended modified Jones model 
of discretionary accruals by Yoon et al. (2006) to measure earnings quality in Malaysian Main Market listed companies. Second, this study examines the effectiveness of directors' independence and internal audit function on earnings quality after the implementation of the revised Code on Corporate Governance, 2007.

\section{Literature Review and Hypotheses Development}

\subsection{Board of Directors' Independence}

Board independence is the basic reason behind the board's monitoring mechanism that is geared to monitor management's actions (Fama \& Jensen, 1983). Jensen and Meckling (1976) stated that non-executive directors may mitigate the agency problems stemming from the management's self-serving behaviours. Empirical evidence has shown that independent directors have negative relationship with discretionary accruals (Abdullah \& Nasir, 2004; Ahmed \& Duellman, 2007; Bekiris \& Doukakis, 2011; Klein, 2002; Park \& Shin, 2004; Salehet al., 2005). This in turn results in high governance monitoring, leading to improving financial reporting quality. This indicates that independent directors lead to high corporate governance effectiveness.

Furthermore, Koh, Laplante and Tong's (2007) study of Australian firms and Benkraiem's (2009) of French firms has highlighted the significant role of independent board of directors in minimizing earnings management. Along the same line, a study conducted by Beekes, Pope and Young (2004) in the U.K. and by Ahmed and Duellman (2007) in the U.S., also supported that high proportion of independent directors in the board is related to high degree of authentic accounting and high earnings quality. In addition, most empirical studies on earnings quality have found that directors' independence is a signal of corporate governance effectiveness and enhanced quality of earnings (Hunton et al., 2011; Siagian \& Tresnaningsih, 2011).

Some studies have shown that high percentage of external directors on the board is effective in limiting earnings management (Peasnell, Pope, \& Young, 2000) and the level of erroneous financial reporting (Beasley, 1996). The Code on Corporate Governance (2001) in Malaysia emphasizes that the composition of independent directors on the board should be at least one third, which is aimed to warrant board independence from any dominant group of members (MCCG, 2001). In the revised Code on Corporate Governance (2012), the tenure of the non-executive directors on the board is an area of concern because over a longer period, the independent judgment of the non-executive directors may be diminished because they are bonded to the insiders, making them more sympathetic, or having interests closely aligned with the insiders.

Empirical studies in the context of Malaysia have provided inconsistent findings. Kamardin and Haron (2011) found that independent directors are not significantly related to the monitoring roles of board of directors. Abdullah and Nasir (2004); Mohamad, et al. (2012) and Buniamin, et al. (2012) showed no influence of independent directors on a firm's earnings quality. Abdullah (2006) revealed that non-executive directors are effective during the financial crisis because investors expect firms to produce financial reports in a timely manner. In addition, Saleh et al. (2005) reported that higher proportion of independent directors cannot limit earnings management. Following the agency theory, we hypothesize that:

\section{$H_{1}$ : Board of directors' independence is negatively associated with discretionary accruals}

\subsection{Audit Committee Independence}

The audit committee is responsible for the evaluation of the integrity of the internal monitoring and risk management system of the company (MCCG, 2001). The audit committee should ensure financial statements comply with applicable financial reporting standards (MCCG, 2012). The agency and resource dependence theories argue that audit committee independence reduces discretionary accruals and enhances the quality of earnings. Several studies that have examined audit committee independence and earnings manipulations support the role of the audit committee. Klein (2002) showed that independence of audit committee is negatively related to abnormal accruals and reduced independence leads to increased abnormal accruals. Studies by Yang and Krishnan (2005); and Mohamed Yunos (2011) have revealed a significantly negative association between independence of audit committee and discretionary accruals. Similarly, Bradbury et al.(2006); Garcia, Barbadillo and Perez (2012); and Salleh, and Haat, (2014) reported that audit committee independence is related to higher earnings quality. Other studies have also found positive association between independent audit committee and earnings quality and the quality of financial reporting (Agrawal \& Chadha, 2005; Ahmad-Zaluki \& Wan-Hussin, 2010; Bedard \& Johnstone, 2004; Bradbury et al., 2006; Klein, 2002; Siagian \& Tresnaningsih, 2011).

Empirical studies in the context of Malaysia have revealed mixed results on the relationship between audit committee independence and earnings quality. Saleh et al. (2007); Salleh, and Haat, (2014); and Mansor et al. (2013) reported that audit committee independence is related to the mitigation of discretionary accruals (proxy of earnings quality). Abdul Rahman and Ali (2006) did not find significant relationship between audit committee 
independence and discretionary accruals. However, Ameer, Ramli and Zakaria (2010) reported that performance of Malaysian firms is better when their audit committee is independent from management. Based on the agency and resource dependence theories, we hypothesize that:

\section{$\mathrm{H}_{2}$ : Audit committee independence is negatively associated with discretionary accruals}

\subsection{Investment in Internal Audit Function}

According to the agency theory, an increase in the internal control system could lead to an increase in the monitoring process of the company to reinforce and increase the financial information outcomes (Jensen \& Meckling, 1976). Internal audit function has become a crucial internal monitoring mechanism in corporate governance (Al-Shetwi, Ramadili, Chowdury, \& Sori, 2011). Prawitt, Smith and Wood (2009) argue that internal audit function is relatively well funded has a greater monitoring ability to detect and deter material misstatements. Increased resources enable the internal audit department to hire and retain more competent personnel.

The MCCG 2007 supports the roles and responsibilities of the internal audit function. The board should set up an internal audit function, which is directly accountable to the audit committee, to recognize and manage risks. Investment in the internal audit function implies more competent internal audit function personnel can help management to establish stronger controls over financial reporting, thus reducing the existence of control problems (Lin, Pizzini, Vargus, \& Bardhan, 2011). Yasin and Nelson (2012) find a positive relationship between external audit quality and cost of internal audit function. Further, Prawitt et al. (2009) find a significant association between internal audit function and absolute abnormal accruals. Thus, we hypothesize that:

\section{$H_{3}$ : Investment in internal audit function is negatively associated with discretionary accruals}

\subsection{Ownership Concentration}

Porta et al. (1999) suggested that the conflict between majority and minority shareholders exists due to the agency problem created by ownership concentration. High ownership concentration provides opportunity to majority shareholders to use the firm's resources at the expense of the minority shareholders (Shleifer \& Vishny, 1986). Fan and Wong (2002) reported that ownership concentration is related to low earnings quality. Yunos et al.(2010) found that ownership concentration is associated with lower accounting conservatism. Abdullah and Nasir (2004); and Abdul Rahman and Mohamed Ali (2006) provided evidence that in the context of Malaysia, board independence is not significantly related to earnings management due to the high ownership concentration in Malaysian companies. Another study by Kamardin and Haron (2011) has suggested that high ownership concentration in Malaysian companies (which are mostly family firms) would result in effective monitoring mechanisms in which the interests of the majority shareholders are in line with the interests of the minority shareholders. Based on the above, we hypothesize that:

\section{$H_{4}$ : Ownership concentration is positively associated with discretionary accruals}

\section{Method}

A total of 822 companies were listed on the Main Market of Bursa (Bourse) Malaysia in the year 2012. In determining the sample for this study, we excluded 51 financial related companies and unit trusts (Yatim, Kent, \& Clarkson, 2006; Yunos et al., 2010); 123 companies having incomplete online annual reports for the period between 2009 and 2012; and 140 companies which had missing data related to the study's variables. The final sample of the study is 508 companies. The period of study is four years (from 2009 to 2012) which resulted in 2,032 firm observations among seven industries (Construction, Consumer, Industrial Product, Plantation, Properties, Technology, Trading and Services). Data was obtained from the annual reports and database.

\subsection{Measurements of Discretionary Accruals}

Previous studies have used discretionary accruals to proxy earnings quality. Two measurements of discretionary accruals are used in this study to see whether the results are consistent for all the models. The first measurement (DA1) follows the Modified Jones Model by Dechow et al. (1995) which has been used in previous studies. Ordinary-Least Square (OLS) cross-sectional regression for all study years and industries are used to estimate the fitted values (coefficients of $a_{1}, a_{2}$, and $a_{3}$ ). The model's equation is as follows:

$$
\mathrm{ACC}_{\mathrm{it}} / \mathrm{TA}_{\mathrm{it}-1}=\mathrm{a}_{0}+\mathrm{a}_{1}\left(1 / \mathrm{TA}_{\mathrm{it}-1}\right)+\mathrm{a}_{2}\left(\Delta \mathrm{REV}_{\mathrm{it}}-\Delta \mathrm{REC}_{\mathrm{it}} / \mathrm{TA}_{\mathrm{it}-1}\right)+\mathrm{a}_{3}\left(\mathrm{PPE}_{\mathrm{it}} / \mathrm{T} \mathrm{A}_{\mathrm{it}-1}\right)+e_{\mathrm{it}}
$$

Where:

$\mathrm{ACC}_{\mathrm{it}}=$ total accruals measured by net income - cash flows from operations

$\mathrm{TA}_{\mathrm{it}-1}=$ prior total assets 
$\Delta \mathrm{REV}_{\mathrm{it}}=$ change in sales/revenue

$\triangle \mathrm{REC}_{\mathrm{it}}=$ change in trade receivables

$\mathrm{PPE}_{\mathrm{it}}=$ property, plant and equipment

$e_{\mathrm{it}}=$ error term

$\mathrm{i}=$ industry

$\mathrm{t}=$ year

Following Dechow et al. (1995), the change in accounts receivable is deducted from the change in revenues before estimation. Then, the industry- and year-specific is used to estimate the parameter estimates (coefficients $\mathrm{a}_{0} ; \mathrm{a}_{1} ; \mathrm{a}_{2} ;$ and $\mathrm{a}_{3}$ ) to infer non-discretionary accruals (NDA) as in equation (2):

$$
\mathrm{NDA}_{\mathrm{it}}=\mathrm{a}_{0}+\mathrm{a}_{1}\left(1 / \mathrm{TA}_{\mathrm{it}-1}\right)+\mathrm{a}_{2}\left(\Delta \mathrm{REV}_{\mathrm{it}}-\Delta \mathrm{REC}_{\mathrm{it}} / \mathrm{TA}_{\mathrm{it}-1}\right)+\mathrm{a}_{3}\left(\mathrm{PPE}_{\mathrm{it}} / \mathrm{T} \mathrm{A}_{\mathrm{it}-1}\right)
$$

The difference between estimation (standardized residuals) in equation (2) and actual accruals represents the total discretionary accruals in the following equation:

$$
\mathrm{DA}_{\mathrm{it}}=\mathrm{ACC}_{\mathrm{it}}-\mathrm{NDA}_{\mathrm{it}}
$$

Where:

$\mathrm{NDA}_{\text {it }}=$ non-discretionary accruals

$\mathrm{DA}_{\mathrm{it}}=$ discretionary accruals from the residuals estimated in model (1)

The second measurement of discretionary accruals (DA2) follows the extended Modified Jones Model by Yoon et al. (2006). Studies in Korea by Yoon and Miller (2002); and Yoon et al. (2006); and a study in Bangladesh by Aminul Islam et al. (2011) have found that the Modified Jones Model by Dechow et al. (1995) does not robust for Asian companies. The model is described in equation (4):

$$
\mathrm{ACC}_{\mathrm{it}} / \mathrm{REV}_{\mathrm{it}}=\beta_{0}+\beta_{1}\left(\Delta \mathrm{REV}_{\mathrm{it}}-\Delta \mathrm{REC}_{\mathrm{it}}\right) / \mathrm{REV}_{\mathrm{it}}+\beta_{2}\left(\Delta \mathrm{EXP}_{\mathrm{it}}-\Delta \mathrm{PAY} \mathrm{Y}_{\mathrm{it}}\right) / \mathrm{REV}_{\mathrm{it}}+\beta_{3}\left(\mathrm{DEP}_{\mathrm{it}}+\mathrm{RET}_{\mathrm{it}}\right) / \mathrm{REV}_{\mathrm{it}}+e_{\mathrm{it}}
$$

Where:

$\triangle \mathrm{EXP}_{\mathrm{it}}=$ change in sum of cost of goods sold and general administrative expenses excluding non-cash expenses

$\triangle \mathrm{PAY}_{\mathrm{it}}=$ change in accounts payable

$\mathrm{DEP}_{\mathrm{it}}=$ depreciation expenses

$\mathrm{RET}_{\mathrm{it}}=$ retirement benefits expenses

Yoon et al.'s (2006) model proposes that the total accruals is related to changes in the cash revenue/sales, change of cash expenses and non-cash expenses of depreciation expenses and the expenses of retirement benefits. Discretionary accruals are accruals minus non-discretionary accruals for each observation as follows:

$\mathrm{DA}_{\mathrm{it}}=\mathrm{TA}_{\mathrm{it}} / \mathrm{REV}_{\mathrm{it}}-\left[\beta_{0}+\beta_{1}\left(\Delta \mathrm{REV}_{\mathrm{it}}-\Delta \mathrm{REC}_{\mathrm{it}}\right) / \mathrm{REV}_{\mathrm{it}}+\beta_{2}\left(\Delta \mathrm{EXP}_{\mathrm{it}}-\Delta \mathrm{PAY} \mathrm{Y}_{\mathrm{it}}\right) / \mathrm{REV}_{\mathrm{it}}+\beta_{3}\left(\mathrm{DEP}_{\mathrm{it}}+\mathrm{RET}_{\mathrm{it}}\right) / \mathrm{REV}_{\mathrm{it}}\right]$

Then the absolute value of discretionary accruals $|\mathrm{DA}|$ represents earnings management because the earnings management can be income-increasing or income-decreasing accruals. Bedard et al. (2004); Klein (2002); Abdul Rahman and Ali (2006); and Prawitt et al. (2009) have suggested that the absolute value of abnormal accruals is a good proxy for the combined effect of income increasing and income decreasing earnings management. Thus, the high absolute value of discretionary accruals indicates low earnings quality and vice versa.

\subsection{Discretionary Accruals Model Specification}

Specifically, this study attempts to examine the relationship between board independence, audit committee independence, internal audit function and ownership concentration and earnings quality. The control variables related to discretionary accruals in previous studies, such as audit quality, profitability, leverage, firm size, net income loss and sales growth are included. The model used to achieve these objectives is as follows:

$$
\begin{gathered}
|\mathrm{DA}|=\beta_{0}+\beta_{1} \text { BDIND }+\beta_{2} \text { ACIND }+\beta_{3} \text { IAF }+\beta_{4} \text { OWCO }+\beta_{5} \text { BIG } 4+\beta_{6} \text { ROA }+\beta_{7} \text { LEV }+\beta_{8} \text { FSIZE }+\beta_{9} \text { LOSS }+ \\
\beta_{10} \text { Growth }+\varepsilon
\end{gathered}
$$

Where:

$|\mathrm{DA}|=$ absolute value of discretionary accruals

BDIND $=$ board of directors' independence 
$\mathrm{ACIND}=$ audit committee independence

$\mathrm{IAF}=$ internal audit function

OWCO $=$ ownership concentration

BIG4 = big 4 audit firms

$\mathrm{ROA}=$ return on assets

$\mathrm{LEV}=$ leverage

FSIZE $=$ firm size

LOSS $=$ net income loss

SGROWTH $=$ sales growth

Table 1 provides a summary of measurements of the study's variables.

Table 1. Summary of measurements of study variables

\begin{tabular}{|c|c|}
\hline Variables & Measurement \\
\hline BDIND & $\begin{array}{l}\text { Percentage of total number of independent non-executive members divided by the total number of board members } \\
\text { (Abdul Rahman \& Ali, 2006; Mohamad et al., 2012). }\end{array}$ \\
\hline ACIND & $\begin{array}{l}\text { Percentage of total number of independent non-executive members divided by the total number of AC members } \\
\text { (Abdul Rahman \& Ali, 2006; Mohamad et al., 2012). }\end{array}$ \\
\hline IAF & The natural log of internal audit cost (Johl, et al., 2013). \\
\hline BIG4 & $\begin{array}{l}\text { Equals " } 1 \text { " if the firm is audited by Big4 Auditors; and "0" otherwise (Abdul Rahman \& Ali 2006; Davidson et } \\
\text { al., 2005). }\end{array}$ \\
\hline OWCO & Largest five shareholders (Gedajlovic \& Shapiro 2002). \\
\hline ROA & $\begin{array}{l}\text { The annual net profit of individual firm before tax divided by total assets (Abdul Rahman \& Ali, 2006; Ismail et } \\
\text { al., 2010). }\end{array}$ \\
\hline LEV & The ratio of total liabilities to total assets (Klein 2002; Davidson et al., 2005). \\
\hline FSIZE & Natural log of total assets (Ismail et al., 2010; Peasnell et al., 2005; Abdul Rahman \& Ali, 2006). \\
\hline LOSS & Dummy variable equal to " 1 " if the net income is less than zero and " 0 " otherwise (Dechow et al., 2003). \\
\hline SGROWTH & Sales growth, annual sales growth (current year sales - prior year's sales)/prior year's sales (Ahmed et al., 2002). \\
\hline
\end{tabular}

\section{Descriptive Statistics and Analysis}

Table 2. Descriptive statistics of continuous variables

\begin{tabular}{ccccccc}
\hline Variables & Minimum & Maximum & Mean & SD & Skewness & Kurtosis \\
\hline DA1 & 0.002 & 0.195 & 0.056 & 0.050 & 1.266 & 4.028 \\
DA2 & 0.007 & 1.452 & 0.256 & 0.338 & 2.258 & 7.801 \\
BDIND & 0.250 & 0.800 & 0.451 & 0.121 & 0.748 & 3.193 \\
ACIND & 0.667 & 1.000 & 0.885 & 0.150 & -0.581 & 1.423 \\
IAF & 8.923 & 15.607 & 11.406 & 1.351 & 0.808 & 3.433 \\
OWCO & 17.850 & 85.730 & 54.241 & 15.735 & -0.147 & 2.415 \\
ROA & -0.320 & 0.265 & 0.034 & 0.093 & -0.892 & 6.647 \\
LEV & 0.004 & 1.652 & 0.391 & 0.220 & 0.997 & 5.710 \\
FSIZE $(\log )$ & 10.402 & 17.453 & 12.897 & 1.440 & 0.863 & 3.692 \\
SGROWTH & -0.593 & 1.581 & 0.071 & 0.337 & 1.818 & 9.254 \\
\hline
\end{tabular}

Descriptive statistics of continuous variables and dichotomous variables are presented in Table 2 and Table 3 , respectively. Table 2 shows that the average board of directors' independence (BDIND) is $45 \%$ with the lowest of $25 \%$ and highest of $80 \%$. It indicates that most companies have complied with the recommendations of the Code on Corporate Governance in Malaysia to have at least one third of the board comprising independent directors, consistent with finding in Yunos et al. (2010). The average percentage of audit committee members being independent directors (ACIND) is $88 \%$, with the minimum of $67 \%$ and maximum of $100 \%$ which complies with the MCCG Code to have majority of independent directors. The average investment on internal audit function (IAF) is 11.41 (RM370,658) with the minimum value being8.92 (RM3,000) and the maximum value being15.61 (RM39,000,000). These results indicate that there is a concerted effort towards investment in internal audit function to increase earnings quality and to enhance the quality of financial reporting in Malaysian 
Main Market listed companies. The average concentrated ownership is $54.24 \%$ with the minimum of $17 \%$ and maximum of $85.73 \%$ which indicates that shares owned by the largest five shareholders on the Malaysia Main Market companies are high. The size of the companies (FSIZE) varies with a minimum of 10.4 and a maximum of 17.45. The average leverage (LEV) is 0.39 and ROA of 0.034 (or 3.4\%). The average sales growth (SGROWTH) of the study sample is $7 \%$.

Table 3 shows that 1,135 firms (55.9\%) were audited by Big4 and 897 firms (44.1) by non-Big 4. This result indicates that most Malaysian listed companies on the Main Market have high quality of external audit which is expected to increase earnings quality.In addition, $21.5 \%$ of the sample companies have net income less than zero (LOSS).

Table 3. Descriptive statistics of dichotomous variables

\begin{tabular}{cccccc}
\hline \multirow{2}{*}{ Variables } & \multirow{2}{*}{ Obs. } & \multicolumn{2}{c}{ Frequency } & \multicolumn{2}{c}{ Percent } \\
\cline { 3 - 6 } & & 1 & 0 & 1 & 0 \\
\hline BIG4 & 2032 & 1135 & 897 & $55.90 \%$ & $44.10 \%$ \\
LOSS & 2032 & 438 & 1,594 & $21.60 \%$ & $78.40 \%$ \\
\hline
\end{tabular}

\subsection{Diagnostic Test}

Following previous studies (e.g., Saleh et al., 2005; Yoon et al., 2006; Ball \& Shavikumar, 2005; Kraft et al., 2014; Bonetti et al., 2013; Gaio, 2010; Kothari et al., 2005; Prawittet et al., 2009), winsorized distribution was conducted to eliminate possible outliers in all continuous variables at the top and bottom one percent of the data distribution to maintain the characteristics of original data. Robust standard errors were conducted to estimate the regression models to solve heteroskedasticity problem. Skewness and kurtosis were used to test the normality assumption; for Skewness, Leys et al. (2013) and Hair et al. (2006) suggested a higher threshold of \pm 3 ; for kurtosis, Kline (1998) suggested a higher threshold of \pm 10 . However, the results from this approach (see Table 4) have led to the conclusion that the data set has no serious violation of the normality assumption; therefore, it is assumed that the data are normally distributed. The correlation matrix between variables using Pearson correlation was conducted to test the multicollinearity issue. As presented in the table, no correlation of more than 0.80 exits (Hair et al., 2006), thus multicollinearity is not an issue in this study.

Table 4. Correlation matrix of variables

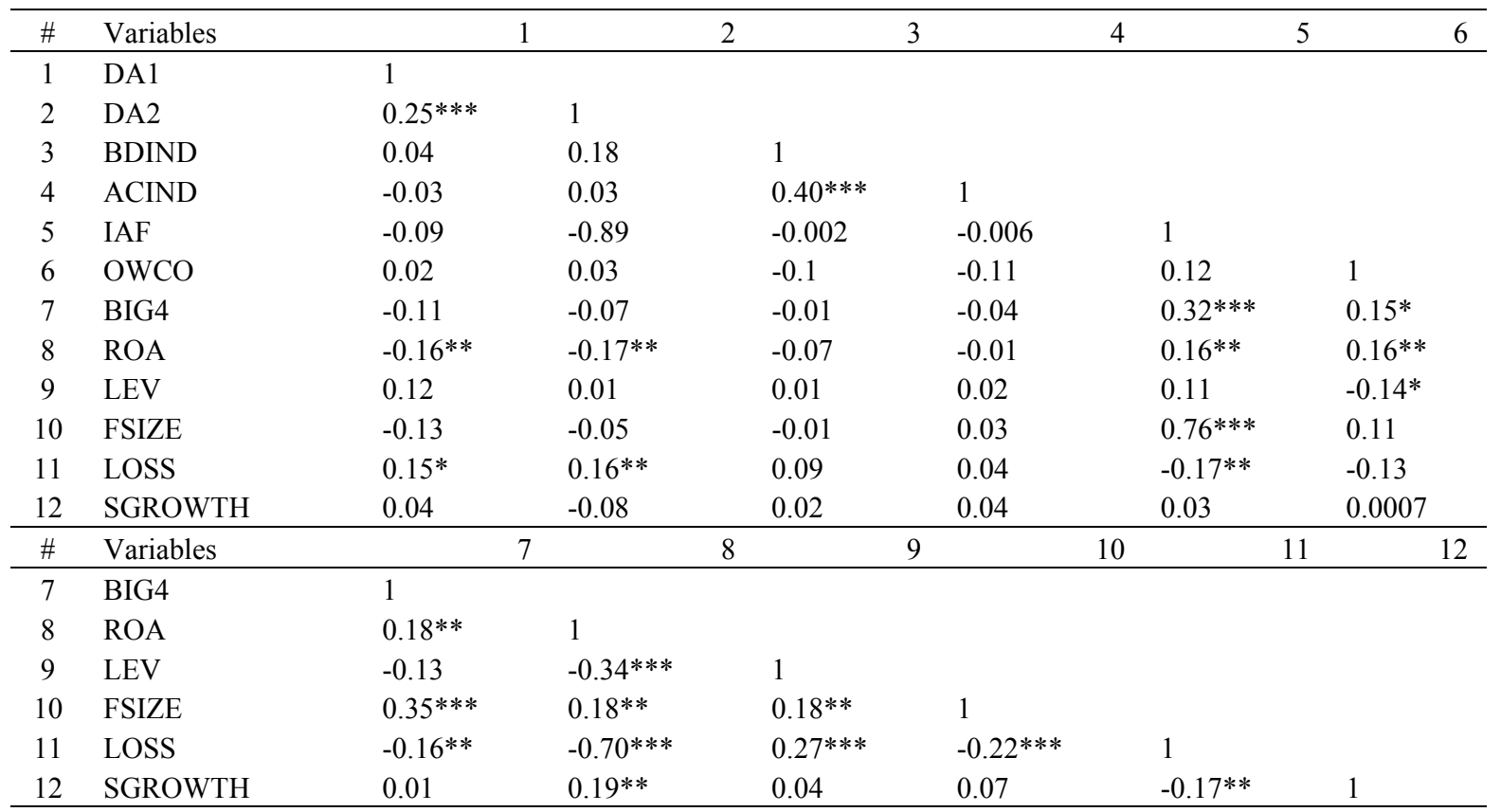

Note: $* * *, * *$, significant level at $10 \%, 5 \%$ and $1 \%$, respectively. DA1 = Discretionary accruals Modified Jones Model (Dechow et al., 1995), DA2 = extended Modified Jones Model (Yoon et al., 2006), BDIND = board independence, ACIND $=\mathrm{AC}$ independence, IAF $=$ cost of internal audit function, BIG4 $=$ largest 4 audit firms, OWCO = Ownership Concentration, $\mathrm{ROA}=$ Return on assets, $\mathrm{LEV}=$ Leverage, FSIZE $=$ Firm size, LOSS $=$ Net Income Loss, $\mathrm{SGROWTH}=$ Sales Growth. 


\section{Results and Discussion}

\subsection{Preliminary Analysis}

Table 7 presents results of the regression analysis. The result shows that the BDIND is significant and positively associated in both models (DA1 and DA2). The result does not support the agency theory and resource dependence theory which suggest that board independence is a monitoring tool to enhance financial reporting quality. This finding contrasts previous studies (Klein, 2002; Xie et al., 2003; Davidson et al., 2005; Chen et al., 2007) which have found that board independence is related to high earnings quality. Thus, $H_{1}$ is rejected. The possible explanation for these results is that the board of directors delegates the responsibility of financial monitoring to the audit committee, which is responsible for reporting the financial status of the corporation (McMullen, 1996; Beasley et al., 2009).

In terms of audit committee independence, the result indicates that ACIND is significant with a negative direction with DA1. Thus, $\mathrm{H}_{2}$ is supported. This result concurs with the agency and resource dependence theories that more independent directors can enhance the monitoring role and bring more resources (expertise and experience) from outside directors which lead to high earnings and financial reporting quality. This result is similar to previous studies done by Klein (2002); Davidson et al. (2005); Saleh et al. (2007); Mansor, et al. (2013); and Salleh, and Haat, (2014). However, the result shows an insignificant association between ACIND and DA2. This result is not consistent with the agency and resource dependence theories' argument that outside directors bring more expertise to enhance the monitoring device in firms and increase the quality of earnings. The insignificant relationship finding is similar to previous findings by Xie et al. (2003); Baxter and Cotter (2009); Garcia et al. (2012); Adiguzel (2013); Abdullah and Nasir (2004); and Abdul Rahman and Ali (2006).

The cost of internal audit function (IAF) is insignificant with DA1 but significant and negatively related to DA2 at the $1 \%$ level. This finding somehow indicates that increasing the cost of IAF would increase internal monitoring by reducing the earnings management and lead to higher earnings quality. This result supports increasing investment in internal audit function as a source to enhance internal monitoring.

The relationship between ownership concentrations (OWCO) is found to be significant with a positive association between OWCO (five largest shareholders) and DA1and DA2; thus, $\mathrm{H}_{3}$ is supported. The findings support the agency theory by high ownership concentration producing high discretionary accruals (or low earnings quality). This finding is consistent with the finding of Fan and Wong (2002). Thus, effective monitoring mechanisms are required in firms with high concentrated ownership.

In relation to the control variables, the result shows that Big4 audit firms have a significant and negative relationship with both discretionary accruals (DA1 and DA2). The result supports the role of audit quality in providing high earnings quality. This result is similar to Becker et al. (1998); Francis et al. (1999); Krishnan (2003); and Chi et al. (2011).

ROA is found to be significant with a negative direction with both discretionary accruals measurements (DA1 and DA2). Thus, the current study finds that firm performance is positively related to earnings quality. This finding is consistent with Abdul Rahman and Ali (2006) who argued that firms with low performance have the tendency to be involved in earnings management.

Meanwhile, leverage (LEV) is found to have a significant and positive relationship with DA1 which indicates that higher leveraged firms are more motivated to engage in earnings manipulation in order to avoid debt covenant violation. In other words, higher leverage leads to a higher level of earnings manipulation. This result is consistent with Klein (2002); and Davidson et al. (2005) who showed that leverage has a significantly positive relationship with earnings management activities; while there is an insignificant relationship between LEV and DA2. This result is similar to previous studies done by Nelson \& Devi (2013); and Abdul Rahman \& Ali (2006).

Firm size (FSIZE) is found to have a significant and negative association with DA1. This result indicates that a large firm reports higher quality of earnings because the financial reporting process is monitored (Yusof et al., 2010; Abdul Rahman \& Ali., 2006; Saleh et al., 2005; Saleh et al., 2007; Mansor et al., 2013). However, the relationship with DA2 is insignificant with positive relationship. The positive result indicates that the large firms report low earnings quality (high discretionary accruals) which is consistent with results by Johl et al. (2013); and Bekiris and Doukakis (2011).

In relation to LOSS, the result shows significant and positive association with both discretionary accruals measurements (DA1 and DA2). This result indicates that firms with loss net income have more earnings management practices (low earnings quality). The results are consistent with Gul et al. (2003); Baxter et al. (2009); and Aerts et al. (2014). 
For sales growth (SGROWTH), the result shows a significant and positive relationship with DA1.This result is consistent with Warfield et al.'s (1995) study which indicates that an increase in sales growth leads to an increase in discretionary accruals (low quality of earnings). Previous studies in Malaysia by Abdul Rahman and Ali (2006); and Johl et al. (2013) have found apositively insignificant association between sales growth and discretionary accruals. However, the sales growth is found to be significant with negative direction with DA2, suggesting that an increase in sales leads to a decrease in discretionary accruals (high earnings quality).

Table 7. Multiple regression results

\begin{tabular}{cccccc}
\hline \multirow{2}{*}{ Variables } & \multirow{2}{*}{ Predicted Sign } & \multicolumn{2}{c}{ DA1 } & \multicolumn{2}{c}{ DA2 } \\
\cline { 3 - 6 } & & Coef. & t-stat & Coef. & t-stat \\
\hline Constant & $?$ & $0.0913^{* * *}$ & 7.39 & $0.155^{*}$ & 1.87 \\
BDIND & - & $0.0241^{* *}$ & 2.42 & $0.292^{* * *}$ & 3.96 \\
ACIND & - & $-0.0189^{* *}$ & -2.38 & -0.0217 & -0.43 \\
IAF & & 0.000422 & 0.33 & $-0.0296^{* * *}$ & -3.3 \\
OWCO & + & $0.000215^{* * *}$ & 3.05 & $0.00155^{* * *}$ & 3.53 \\
BIG4 & - & $-0.00525^{* *}$ & -2.24 & $-0.0303^{*}$ & -1.83 \\
ROA & - & $-0.0473^{*}$ & -1.67 & $-0.517^{* * *}$ & -2.76 \\
LEV & + & $0.0216^{* * *}$ & 3.42 & $-0.0756^{*}$ & -1.66 \\
FSIZE & - & $-0.00403^{* * *}$ & -3.4 & $0.0230^{* * *}$ & 2.71 \\
LOSS & + & $0.00690^{*}$ & 1.79 & $0.0560^{*}$ & 1.88 \\
SGROWTH & + & $0.0104^{* * *}$ & 2.65 & $-0.0494^{*}$ & -1.81 \\
R & +0.0609 & & 0.0582 & 7.51 \\
F-value & & 11.24 & & 0 & \\
Sig & & 0 & & & \\
N & & 2032 & & \\
\hline
\end{tabular}

Where: $* * *, * *$ Significant level at $0.10,0.05$, and 0.01 , respectively. DA1 $=$ Discretionary accruals Modified Jones Model (Dechow et al., 1995), DA2 = Modified Jones Model (Yoon et al., 2006), BDIND = board independence, ACIND $=\mathrm{AC}$ independence, IAF $=$ cost of internal audit function, BIG4 = largest 4 audit firms, OWCO5 = Ownership Concentration, $\mathrm{ROA}=$ Return on assets, $\mathrm{LEV}=$ Leverage, FSIZE $=$ Firm size, LOSS $=$ Net Income Loss, SGROWTH $=$ Sales growth.

\subsection{Additional Sensitivity Analysis}

Additional analysis were conducted to determine the sensitivity of the results as well as to determine the robustness of the findings reported earlier in Table 7. The repeated regression models allowing for a possible different relationship between audit committee independence and earnings quality. The study model was further tested by creating a new variable of audit committee independence measured by dummy variable" 1 " if all audit committee members are independent and " 0 " otherwise, rather than percentage of audit committee independence to audit committee size. Results in Table 8 show that the coefficients of the relationship between audit committee independence and earnings quality are consistent.

Table 8. Multiple regression results

\begin{tabular}{|c|c|c|c|c|c|}
\hline \multirow{2}{*}{ Variables } & \multirow{2}{*}{$\begin{array}{l}\text { Predicted } \\
\text { Sign }\end{array}$} & \multicolumn{2}{|c|}{ DA1 } & \multicolumn{2}{|c|}{$\mathrm{DA} 2$} \\
\hline & & Coef. & t-stat & Coef. & t-stat \\
\hline Constant & $?$ & $0.0797 * * *$ & 7.07 & $0.142 *$ & 1.87 \\
\hline BDIND & - & $0.0241 * *$ & 2.44 & $0.297 * * *$ & 4.07 \\
\hline ACIND & - & $-0.00619 * *$ & -2.51 & -0.0105 & -0.68 \\
\hline IAF & - & 0.000391 & 0.31 & $-0.0297 * * *$ & -3.31 \\
\hline OWCO & + & $0.000213 * * *$ & 3.01 & $0.00154 * * *$ & 3.5 \\
\hline BIG4 & - & $-0.00519 * *$ & -2.22 & $-0.0304^{*}$ & -1.83 \\
\hline $\mathrm{ROA}$ & - & $-0.0477 *$ & -1.69 & $-0.516 * * *$ & -2.76 \\
\hline LEV & + & $0.0216 * * *$ & 3.42 & $-0.0756^{*}$ & -1.67 \\
\hline FSIZE & - & $-0.00408 * * *$ & -3.44 & $0.0230 * * *$ & 2.72 \\
\hline LOSS & + & $0.00684 *$ & 1.78 & $0.0560^{*}$ & 1.89 \\
\hline SGROWTH & + & $0.0104 * * *$ & 2.66 & $-0.0492 *$ & -1.8 \\
\hline $\mathrm{R}^{2}$ & & \multicolumn{2}{|c|}{0.0612} & \multicolumn{2}{|c|}{0.0583} \\
\hline F-value & & \multicolumn{2}{|c|}{11.31} & \multicolumn{2}{|c|}{7.53} \\
\hline Sig & & \multicolumn{2}{|c|}{0} & \multicolumn{2}{|c|}{0} \\
\hline $\mathrm{N}$ & & \multicolumn{2}{|c|}{2032} & \multicolumn{2}{|c|}{2032} \\
\hline
\end{tabular}


Where: *,**,*** Significant level at $0.10,0.05$, and 0.01 , respectively. DA1 $=$ Discretionary accruals Modified Jones Model (Dechow et al., 1995), DA2 = Modified Jones Model (Yoon et al., 2006), BDIND = board independence, ACIND $=\mathrm{AC}$ independence, IAF $=$ cost of internal audit function, BIG4 = largest 4 audit firms, OWCO5 = Ownership Concentration, $\mathrm{ROA}=$ Return on assets, $\mathrm{LEV}=$ Leverage, FSIZE $=$ Firm size, LOSS $=$ Net Income Loss, $\mathrm{SGROWTH}=$ Sales growth.

\section{Conclusion}

We examined the effect of board and audit committee independence, quality of internal audit function and ownership concentration on earnings quality, measured by absolute value of discretionary accruals. We have found some evidence that audit committee independence and more investment in internal audit function related to high level of earnings quality. However, the study has found evidence that board independence and ownership concentration are associated with low earnings quality. In addition, external audit by Big4 firms also increases the level of earnings quality. The findings are consistent for both measures of earnings quality in relation to board characteristics. This study contains a number of limitations; first limitation is study sample only Malaysia Main Market listed companies. Second limitation is the study covered only four years, Lastly, limitations related of other independent variables which may influence on earning quality and internal monitoring mechanisms such as other board and audit committee characteristics, ownership structure, because Malaysian companies have high ownership concentration that may affect the monitoring function of board and audit committee. We recommend that future research should examine other variables of audit committee characteristics (size, independence, expertise, etc.) and other ownership structures on the relationship with earnings quality.

\section{References}

Abdul Rahman, R. A., \& Ali, F. H. M. (2006). Board, audit committee, culture and earnings management: Malaysian evidence. Managerial Auditing Journal, 21(7), 783-804. http://dx.doi.org/10.1108/02686900 610680549

Abdullah, S. N. (1999). The role of corporate governance and ownership structure on accounting earnings quality (Unpublished PhD Dissertation). Universiti Utara Malaysia, Kedah, Malaysia.

Abdullah, S. N. (2006). Directors' remuneration, firm's performance and corporate governance in Malaysia among distressed companies. Corporate Governance, 6(2), 162-174. http://dx.doi.org/10.1108/14720700 610655169

Abdullah, S. N., \& Nasir, N. M. (2004). Accrual management and the independence of the Boards of Directors and Audit Committees. International Journal of Economics, Management and Accounting, 12(1), 49-80. Retrieved from http://repo.uum.edu.my/id/eprint/1755

Adiguzel, H. (2013). Corporate Governance, Family Ownership and Earnings Management: Emerging Market Evidence. Accounting and Finance Research, 2(4), 17. http://dx.doi.org/10.5430/afr.v2n4p17

Aerts, W., \& Zhang, S. (2014). Management's causal reasoning on performance and earnings management. European Management Journal. http://dx.doi.org/10.1016/j.emj.2013.12.006

Agrawal, A., \& Chadha, S. (2005). Corporate Governance and Accounting Scandals. Journal of Law and Economics, 48(2), 371-406.

Ahmad-Zaluki, N. A., \& Wan-Hussin, W. N. (2010). Corporate governance and earnings forecasts accuracy. Asian Review of Accounting, 18(1), 50-67. http://dx.doi.org/10.1108/13217341011046006

Ahmed, A. S., \& Duellman, S. (2007). Accounting conservatism and board of director characteristics: An empirical analysis. Journal of Accounting and Economics, 43(2), 411-437. http://dx.doi.org/10.2139/ssrn. 887301

Ahmed, A. S., Billings, B. K., Morton, R. M., \& Stanford-Harris, M. (2002). The role of accounting conservatism in mitigating bondholder-shareholder conflicts over dividend policy and in reducing debt costs. The Accounting Review, 77(4), 867-890. Retrieved from http:/www.jstor.org/stable/3068874

Al-Shetwi, M., Ramadili, S. M., Chowdury, T. H. S., \& Sori, Z. M. (2011). Impact of internal audit function (IAF) on financial reporting quality (FRQ): Evidence from Saudi Arabia. African Journal of Business Management, 5(27), 11189-11198. http://dx.doi.org/10.5897/AJBM11.1805

Ameer, R., Ramli, F., \& Zakaria, H. (2010).A new perspective on board composition and firm performance in an emerging market. Corporate Governance, 10(5), 647-661. http://dx.doi.org/10.1108/14720701011085607

Ball, R., \& Shivakumar, L. (2005). Earnings quality in UK private firms: comparative loss recognition timeliness. 
Journal of Accounting and Economics, 39(1), 83-128. http://dx.doi.org/10.1016/j.jacceco.2004.04.001

Baxter, P., \& Cotter, J. (2009). Audit committees and earnings quality. Accounting \& Finance, 49(2), 267-290. http://dx.doi.org/10.1111/j.1467-629X.2008.00290.x

Beasley, M. S. (1996). An empirical analysis of the relation between the board of director composition and financial statement fraud. Accounting Review, 443-465. Retrieved from http://www.jstor.org/stable/248566

Beasley, M. S., Carcello, J. V., Hermanson, D. R., \& Neal, T. L. (2009). The Audit Committee Oversight Process. Contemporary Accounting Research, 26(1), 65-122.

Becker, C. L., DeFond, M. L., Jiambalvo, J., \& Subramanyam, K. R. (1998). The effect of audit quality on earnings management. Contemporary accounting research, 15(1), 1-24. Retrieved from http://ssrn.com/abstract $=44835$

Bedard, J. C., \& Johnstone, K. M. (2004). Earnings manipulation risk, corporate governance risk, and auditors' planning and pricing decisions. The Accounting Review, 79(2), 277-304. Retrieved from http://ssrn.com/abstract $=934192$

Beekes, W., Pope, P., \& Young, S. (2004). The link between earnings timeliness, earnings conservatism and board composition: evidence from the UK. Corporate Governance: An International Review, 12(1), 47-59. Retrieved from http://ssrn.com/abstract=513421

Bekiris, F. V., \& Doukakis, L. C. (2011). Corporate Governance and Accruals Earnings Management. Managerial and Decision Economics, 32(7), 439-456. http://dx.doi.org/10.1002/mde.1541

Benkraiem, R. (2009). Does the presence of independent directors influence accruals management? Journal of Applied Business Research (JABR), 25(6).

Bonetti, P., Parbonetti, A., \& Magnan, M. (2013). The Influence of Country-and Firm-Level Governance on Financial Reporting Quality: Revisiting the Evidence. CIRANO-Scientific Publications 2013s-03. http://dx.doi.org/10.2139/ssrn.2212200

Bradbury, M., Mak, Y. T., \& Tan, S. (2006). Board characteristics, audit committee characteristics and abnormal accruals. Pacific Accounting Review, 18(2), 47-68. http://dx.doi.org/10.1108/01140580610732813

Buniamin, S., Johari, N. H., Rahman, N. R. A., \& Rauf, F. H. A. (2012). Board diversity and discretionary accruals of the Top 100 Malaysia corporate governance (MCG) index company. African Journal of Business Management, 6(29), 8496-8503. http://dx.doi.org/10.5897/AJBM11.1052

Chen, K. Y., \& Zhou, J. (2007). Audit Committee, Board Characteristics, and Auditor Switch Decisions by Andersen's Clients. Contemporary Accounting Research, 24(4), 1085-1117. Retrieved from http://ssrn.com/abstract $=980938$

Chi, W., Lisic, L. L., \& Pevzner, M. (2011). Is enhanced audit quality associated with greater real earnings management? Accounting Horizons, 25(2), 315-335. Retrieved from http://ssrn.com/abstract=1904481

Dahya, J., Dimitrov, O., \& McConnell, J. J. (2008). Dominant shareholders, corporate boards, and corporate value: A cross-country analysis. Journal of Financial Economics, 87(1), 73-100. http://dx.doi.org/10.1016/ j.jfineco.2006.10.005

Davidson, R., Goodwin-Stewart, J., \& Kent, P. (2005). Internal Governance Structures and Earnings Management. Accounting \& Finance, 45(2), 241-267. http://dx.doi.org/10.1111/j.1467-629x.2004.00132.x

Dechow, P. M., Richardson, S. A., \& Tuna, I. (2003). Why are earnings kinky? An examination of the earnings management explanation. Review of accounting studies, 8(2-3), 355-384. http://dx.doi.org/10.1023/A: 1024481916719

Dechow, P. M., Sloan, R. G., \& Sweeney, A. P. (1995). Detecting earnings management. Accounting Review, 193-225. Retrieved from http://www.jstor.org/stable/248303

Fama, E. F., \& Jensen, M. C. (1983). Agency problems and residual claims. Journal of Law and Economics, 327-349. Retrieved from http://www.jstor.org/stable/725105

Fan, J. P., \& Wong, T. J. (2002). Corporate ownership structure and the informativeness of accounting earnings in East Asia.Journal of Accounting and Economics, 33(3), 401-425. http://dx.doi.org/10.1016/S0165-4101 (02)00047-2

Francis, J., \& Schipper, K. (1999). Have financial statements lost their relevance? Journal of Accounting Research, 37(2), 319-352. Retrieved from http://www.jstor.org/stable/2491412 
Gaio, C. (2010). The relative importance of firm and country characteristics for earnings quality around the world. European Accounting Review, 19(4), 693-738. http://dx.doi.org/10.1080/09638180903384643

Garcia, L. S., Barbadillo, E. R., \& Pérez, M. O. (2012). Audit committee and internal audit and the quality of earnings: empirical evidence from Spanish companies. Journal of Management \& Governance, 16(2), 305-331. http://dx.doi.org/10.1007/s10997-010-9152-3

Gedajlovic, E., \& Shapiro, D. M. (2002). Ownership structure and firm profitability in Japan. Academy of Management Journal, 45(3), 565-575.

Gul, F. A., Chen, C. J., \& Tsui, J. S. (2003). Discretionary Accounting Accruals, Managers' Incentives, and Audit Fees. Contemporary Accounting Research, 20(3), 441-464. http://dx.doi.org/10.1506/686E-NF2J-73X6G540

Hair, J. F., Tatham, R. L., Anderson, R. E., \& Black, W. (2006). Multivariate data analysis (Vol. 6). Upper Saddle River, NJ: Pearson Prentice Hall.

Hashim, H. A., \& Devi, S. S. (2007). Corporate governance, ownership structure and earnings quality: Malaysian evidence. Research in Accounting and Emerging Economies, 8, 97-123.

Hunton, J. E., Hoitash, R., \& Thibodeau, J. C. (2011). The relationship between perceived tone at the top and earnings quality. Contemporary Accounting Research, 28(4), 1190-1224. http://dx.doi.org/10.1111/j.19113846.2011.01100.x

Islam, M. A., Ali, R., \& Ahmad, Z. (2014). Is modified Jones model effective in detecting earnings management? Evidence from a developing economy. International Journal of Economics and Finance, 3(2), 116. http://dx.doi.org/10.5539/ijef.v3n2p116

Ismail, W. A. W., Dunstan, K. L., \& Van Zijl, T. (2010). Earnings quality and corporate governance following the implementation of Malaysian code of corporate governance. PDF file, 40. Retrieved from http://www.researchgate.net/profile/Wan_Adibah_Wan_Ismail/publication/228121833_Earnings_Quality_a nd_Corporate_Governance_Following_the_Implementation_of_Malaysian_Code_of_Corporate_Governanc e/links/0deec52d24feac7bff000000.pdf

Jensen, M. C., \& Meckling, W. H. (1976). Theory of the firm: Managerial behavior, agency costs and ownership structure. Journal of Financial Economics, 3(4), 305-360. http://dx.doi.org/10.2139/ssrn.94043

Johl, S. K., Johl, S. K., Subramaniam, N., \& Cooper, B. (2013). Internal audit function, board quality and financial reporting quality: evidence from Malaysia. Managerial Auditing Journal, 28(9), 1-1. http://dx.doi.org/10.1108/MAJ-06-2013-0886

Kamardin, H., \& Haron, H. (2011). Internal corporate governance and board performance in monitoring roles: evidence from Malaysia. Journal of Financial Reporting and Accounting, 9(2), 119-140. http://dx.doi.org/10.1108/19852511111173095

Klein, A. (2002). Audit committee, board of director characteristics, and earnings management. Journal of Accounting and Economics, 33(3), 375-400. http://dx.doi.org/10.1016/S0165-4101(02)00059-9

Koh, P. S., Laplante, S. K., \& Tong, Y. H. (2007). Accountability and value enhancement roles of corporate governance. Accounting \& Finance, 47(2), 305-333. http://dx.doi.org/10.1111/j.1467-629X.2006.00207.x

Kothari, S. P., Leone, A. J., \& Wasley, C. E. (2005). Performance matched discretionary accrual measures. Journal of Accounting and Economics, 39(1), 163-197. http://dx.doi.org/10.1016/j.jacceco.2004.11.002

Kraft, A., Lee, B. S., \& Lopatta, K. (2014). Management earnings forecasts, insider trading, and information asymmetry. Journal of Corporate Finance, 26, 96-123. http://dx.doi.org/10.1016/j.jcorpfin.2014.03.002

Krishnan, G. V. (2003). Audit quality and the pricing of discretionary accruals. Auditing: A Journal of Practice \& Theory, 22(1), 109-126. http://dx.doi.org/10.2139/ssrn.320164

Leys, C., Ley, C., Klein, O., Bernard, P., \& Licata, L. (2013). Detecting outliers: Do not use standard deviation around the mean, use absolute deviation around the median. Journal of Experimental Social Psychology, 49(4), 764-766. http://dx.doi.org/10.1016/j.jesp.2013.03.013

Lin, S., Pizzini, M., Vargus, M., \&Bardhan, I. R. (2011). The role of the internal audit function in the disclosure of material weaknesses. The Accounting Review, 86(1), 287-323. http://dx.doi.org/http://dx.doi.org/10.2308/ accr.00000016

Mansor, N., Che-Ahmad, A., Ahmad-Zaluki, N. A., \& Osman, A. H. (2013). Corporate Governance and Earnings 
Management: A Study on the Malaysian Family and Non-family Owned PLCs. Procedia Economics and Finance, 7, 221-229. http://dx. Doi.10.1016/S2212-5671(13)00238-4

McMullen, D. A., \& Raghunandan, K. (1996). Enhancing audit committee effectiveness. Journal of Accountancy, $182,79-81$.

Mohamad, M. H. S., Rashid, H. M. A., \& Shawtari, F. A. M. (2012). Corporate governance and earnings management in Malaysian government linked companies: The impact of GLCs' transformation policy. Asian Review of Accounting, 20(3), 241-258. http://dx.doi.org/10.1108/13217341211263283

Mohamed Yunos, R. (2011). The effect of ownership concentration, board of directors, audit committee and ethnicity on conservative accounting: Malaysian evidence. Retrieved from http://ro.ecu.edu.au/theses/155

Nelson, S. P., \& Devi, S. (2013). Audit committee experts and earnings quality. Corporate Governance, 13(4), 335-351. http://dx.doi.org/10.1108/CG-02-2011-0009

Park, Y. W., \& Shin, H.-H. (2004). Board composition and earnings management in Canada. Journal of Corporate Finance, 10(3), 431-457. http://dx.doi.org/10.1016/S0929-1199(03)00025-7

Peasnell, K. V., Pope, P. F., \& Young, S. (2000). Detecting earnings management using cross-sectional abnormal accruals models. Accounting and Business Research, 30(4), 313-326. http://dx.doi.org/10.1080/00014788. 2000.9728949

Peasnell, K. V., Pope, P. F., \& Young, S. (2005). Board monitoring and earnings management: do outside directors influence abnormal accruals?. Journal of Business Finance \& Accounting, 32(7-8), 1311-1346. http://dx.doi.org/10.1111/j.0306-686X.2005.00630.x

Pfeffer Pfeffer, J., \& Salancik, G. (2003). The external control of organizations: A resource dependence perspective. Stanford, CA: Stanford Business Books.

Porta, R., Lopez-De-Silanes, F., \& Shleifer, A. (1999).Corporate ownership around the world. The Journal of Finance, 54(2), 471-517.

Prawitt, D. F., Smith, J. L., \& Wood, D. A. (2009). Internal audit quality and earnings management. The Accounting Review, 84(4), 1255-1280. http://dx.doi.org/10.2308/accr.2009.84.4.1255

Saleh, N. M., Iskandar, T. M., \& Rahmat, M. M. (2007). Audit committee characteristics and earnings management: evidence from Malaysia. Asian Review of Accounting, 15(2), 147-163. http://dx.doi.org/10.1108/13217340710823369

Saleh, N. M., Iskandar, T. M., \&Rahmat, M. M. (2005). Earnings management and board characteristics: Evidence from Malaysia. JurnalPengurusan, 24, 77-103.

Salleh, N. M. Z. N., \& Haat, M. H. C (2014). Audit committee and earnings management: Pre and Post MCCG. International Review of Management and Business Research, 3(1), 307-318

Shleifer, A., \& Vishny, R. W. (1986). Large shareholders and corporate control. The Journal of Political Economy, 461-488. http://dx.doi.org/10.1086/261385

Siagian, F. T., \& Tresnaningsih, E. (2011). The impact of independent directors and independent audit committees on earnings quality reported by Indonesian firms. Asian Review of Accounting, 19(3), 192-207. http://dx.doi.org/10.1108/13217341111185128

Warfield, T. D., Wild, J. J., \& Wild, K. L. (1995). Managerial ownership, accounting choices, and informativeness of earnings. Journal of accounting and economics, 20(1), 61-91. http://dx.doi.org/10.1016/ 0165-4101(94)00393-J

Xie, B., Davidson, W. N., \& DaDalt, P. J. (2003). Earnings management and corporate governance: the role of the board and the audit committee. Journal of Corporate Finance, 9(3), 295-316. http://dx.doi.org/10.1016/ S0929-1199(02)00006-8

Yang, J. S., \& Krishnan, J. (2005). Audit committees and quarterly earnings management. International Journal of Auditing, 9(3), 201-219. Retrieved from http://ssrn.com/abstract=845145

Yassin, F. M., \& Nelson, S. P. (2012). Audit Committee and Internal Audit: Implications on Audit Quality. International Journal of Economics, Management and Accounting, 20(2).

Yatim, P., Kent, P., \& Clarkson, P. (2006). Governance structures, ethnicity, and audit fees of Malaysian listed firms. Managerial Auditing Journal, 21(7), 757-782. http://dx.doi.org/10.1108/02686900610680530 
Yoon, S. S., \& Miller, G. (2002). Earnings management of seasoned equity offering firms in Korea. The international journal of accounting, 37(1), 57-78. http://dx.doi.org/10.1016/S0020-7063(02)00140-1

Yoon, S. S., Miller, G., \&Jiraporn, P. (2006). Earnings management vehicles for Korean firms. Journal of International Financial Management \& Accounting, 17(2), 85-109. http://dx.doi.org/10.1111/j.1467646X.2006.00122.x

Yunos, R. M., Smith, M., \& Ismail, Z. (2010). Accounting conservatism and ownership concentration: Evidence from Malaysia. Journal of Business and Policy Research, 5(2), 1-15.

Yusof, M. (2010). Does audit committee constraint discretionary accruals in MESDAQ Listed Companies? International Journal of Business and Social Science, 1(3), 124-136. http://dx.doi.org/10.2139/ssrn. 1363632

\section{Copyrights}

Copyright for this article is retained by the author(s), with first publication rights granted to the journal.

This is an open-access article distributed under the terms and conditions of the Creative Commons Attribution license (http://creativecommons.org/licenses/by/3.0/). 